\title{
Leader Appeal, Leader Performance, and the Motive Profiles of Leaders and Followers: A Study of American Presidents and Elections
}

\author{
David G. Winter \\ Wesleyan University
}

\begin{abstract}
Three leader trait and leader-follower interaction models of leader appeal and leader performance are evaluated with data about the motive profiles of American presidents and American society, in both cases measured at a distance. Presidential appeal, defined in terms of electoral success, is significantly correlated with the congruence or match between the president's motive profile and that of his contemporary society. In contrast, presidential greatness, as rated by historians, as well as several important outcomes involving war and peace are associated with certain of the president's motives by themselves, but not with president-society congruence.
\end{abstract}

What is a great leader? What is a popular leader? Are they the same? Are they the result of the same or different factors? Our naive belief in the "great person" theory of leadership, that the person shapes events and the leader creates his or her own greatness, has long been challenged by scholars from diverse disciplines who analyze leadership appeal and performance into broad impersonal forces and social-structural factors. Yet in the real world of politics, the factor of personal appeal or having (in the language of the Harris poll) "an attractive, forceful personality" is of enormous concern to campaign strategists and journalists (even if it is largely treated as error variance by voting analysts; see Nie, Verba, \& Petrocik, 1979; Sears, 1969). And in the real world of history, successful leaders such as Abraham Lincoln or Franklin D. Roosevelt display such a blend of wisdom, flexibility, and good tactics that we conclude their greatness must be based, at least in part, on personal characteristics (e.g., see Burns, 1956; Haley, 1969; Vidal, 1984).

Can these phenomena of greatness and appeal among political leaders be analyzed in psychological terms? Several classic theories and a good deal of contemporary social psychological research suggest a variety of models for a leader's appeal and performance. This article presents data on the psychological characteristics of one kind of leader-American presidentsand one series of followers-American society from the 1780s through the 1960s-as an empirical commentary on (not a test of) these theories and issues.

\section{Theories and Models of Leader Appeal}

\section{Leader Characteristics}

Max Weber's concept of charisma (or the "gift of grace") as one base of the legitimacy of authority is obviously related to

The research reported in this article was supported by grants from the John and Mary R. Markle Foundation. I am grateful to Joseph M. Healy, Jr., for assistance in the analysis of data.

An earlier version of this article was presented at the symposium "Personality and Political Belief Systems" at the meeting of the American Psychological Association in Toronto, Canada, August 1984.

Correspondence concerning this article should be addressed to David G. Winter, Psychology Department, Wesleyan University, Middletown, Connecticut 06457. the leader's personal appeal and performance when structural and traditional factors are held constant. To Weber, the charismatic leader possesses "a certain quality of personality by virtue of which he is set apart from ordinary men and treated as endowed with supernatural, superhuman, or at least specifically exceptional powers or qualities." Followers obey out of duty rather than choice or calculation; as Weber put it, "No prophet has ever regarded his quality [of charisma] as dependent on the attributes of the masses around him." Of course Weber did acknowledge that in the long run the followers' needs and satisfactions are important. "If [the leader] is for long unsuccessful, above all if his leadership fails to benefit his followers, it is likely that his charismatic authority will disappear" (1947, pp. 358-360).

Although Freud analyzed the dynamics of group formation in terms of the followers' identification in their ego ideal or superego with the leader, he emphasized the characteristics of the successful leader in facilitating these identifications. "The leader himself need love no one else, he may be of a masterful nature, absolutely narcissistic, self-confident, and independent" (1921/1955, pp. 123-124).

Thus one psychological model of political leaders' appeal and success focuses on relatively enduring personal characteristics (e.g., narcissism, energy, self-direction) that some leaders simply happen to possess. Although the great-person theory of leadership implicit in this model is now in some disrepute (see Gibb, 1969; Hollander, 1964), many experimental studies do show the modest positive correlations between leadership and self-esteem, self-confidence, and related variables (see Bass, 1981, pp. 74-92) that would be predicted from the Weber-Freud model.

\section{Leader-Situation Match}

Nowadays many theorists and most experimentalists would argue that the leader's appeal and success depend on the situation, so that the personality characteristics required for successful, appealing leadership will vary with the situation. Recently Bem and Funder (1978) and Bem and Lord (1979) have expressed this notion more formally in the concept of the degree of match between a person and the template (required characteristics) of the situation, and they have gone on to suggest ways of measuring situational demands. 
Barber's (1980) recent cyclical model of American elections is an application of the notion of leader-situation template matching or congruence in a political context. According to Barber, American presidential elections follow a regular course: first, a focus on conflict of forces; then, a concern for conscience; and finally, a need for conciliation to bring all parties together again. This leads, in turn, to a renewed conflict orientation. From election to election the requirements for personal appeal and success in office might vary in a corresponding fashion: In a "conflict" year, the candidate who is the best fighter will be appealing and victorious, but when the concern is with conciliation, the candidate who promises to "bring us together" will gain popular appeal. Barber believed that these three issues are derived from the most basic social-political aspects of human nature; that the cyclical dynamic has a force of its own. Thus his theory involves a kind of match between leader and situation, but the situation is conceived in terms of abstract, impersonal forces rather than in terms of particular personal characteristics of the followers.

\section{Leader-Follower Match}

In contrast to the impersonal cycle of Barber's theory, Erikson offered a theory of the relation between leaders and their societies that is explicitly focused on the relation between leaders' and followers' characteristics. On the basis of several studies of "inspiring and effective [men] of action" such as Hitler, Luther, and Gandhi (Erikson, 1950, 1958, and 1969, respectively), Erikson concluded that leaders, with their own identities, conflicts, and needs, are "found and chosen by contemporaries possessed of analogous conflicts and corresponding needs" (1964, p. 204). In other words, the success of such leaders depends on a match between their own personal characteristics and the historically conditioned characteristics of their potential followers. Phrased in this way Erikson's theory is supported by the extensive experimental literature relating leadership success to a kind of congruence between leaders' characteristics and followers' characteristics (see Bass, 1981, pp. 31-33). Erikson also mentioned some transsituational abilities of the leader, but they are not formally incorporated into his theory: "An unusual energy of body, a rare concentration of mind, and a total devotion of soul. . . . Intuitive grasp of the actualities of the led . . . [and] ability to introduce himself into that actuality as a new, vital factor (personality, image, style)" (1964, pp. 203, 208).

Taken together, these theories suggest several different kinds of factors that may account for the personal appeal and greatness of political leaders: (a) leader characteristics independent of the situation, (b) leader characteristics that match systematically changing situational demands, and (c) leader characteristics that match characteristics of followers or of the population in general, whatever the determinants of these latter characteristics may be.

The several explanations of leadership are quite parallel to familiar psychological explanations of other behaviors: an initial person or "trait" explanation (e.g., Allport, 1937), later debunked for a time (e.g., Mischel, 1968), and followed by a focus on the interaction of person and situation (e.g., Magnusson \& Endler, 1977). The rest of this article will explore the usefulness of these models by analyzing American presidents and presidential elections. Some questions to be asked include: What is the psychological basis of presidential appeal? Does it involve leader characteristics or some kind of leader-situation match? What is the psychological basis of presidential greatness? Are the leaders who appeal the most to the electorate also the greatest or best leaders? In some sense, this last question reaches down to the foundations of democratic political theory. (See Simonton, 1981, for a study of other, nonpsychological determinants of presidential greatness.)

\section{Empirical Studies of Presidents and Elections}

The American presidency is an excellent source of material for studying the appeal and performance of political leaders. Although the size of the population is rather small, the efforts of historians, political scientists, and archivists have accumulated an enormous amount of data. In recent years, many scholars have begun to analyze the presidency with the quantitative and statistical methods familiar to the behavioral sciences (e.g., Maranell, 1970; Murray \& Blessing, 1983; Simonton, 1981). Recent advances in the technology for assessing the personalities of key political actors at a distance (cf. Hermann, 1977) and measuring the modal personality of groups of followers over time through coding cultural documents (e.g., McClelland, 1961, 1975, especially Appendix IV) have made it possible to study, in psychological terms, the leadership appeal and performance of American presidents in their society.

For both leaders and followers, this study focuses on three important human social motives: (a) the achievement motive, a concern for excellence, which is associated with moderate risk taking, using feedback, and entrepreneurial success (McClelland, 1961); (b) the affiliation-intimacy motive, a concern for close relations with others, which is associated with interpersonal warmth, self-disclosure, and good overall adaptation to life (McAdams, 1982); and (c) the power motive, a concern for impact and prestige, which is associated with getting formal social power and also profligate impulsive actions such as aggression, drinking, and taking extreme risks (Winter, 1973; Winter \& Stewart, 1978).

Motivation focuses on the broad classes of people's goals and goal-directed actions, and so it is a component of personality that is especially important to the relations between leaders and followers. These particular motives are drawn from Murray's comprehensive taxonomy. Although they are not the only human motives, several lines of evidence do suggest that they are major motives involving the most important common human concerns. Power and affiliation, for example, repeatedly emerge as the two fundamental dimensions of social behavior (see Brown, 1965, chapter 2) and interpersonal traits (Conte \& Plutchik, 1981; Wiggins, 1980). Achievement reflects the dimension of evaluation that is consistently the most important factor of connotative meaning (Snider \& Osgood, 1969). These three motives are closely matched to the three dimensions used by Bales (1970) to describe group functioning (forward-backward, positive-negative, and upward-downward, respectively).

Winter and Stewart (1977) have demonstrated that these three motives are relevant to several important kinds of political action and outcomes. Whereas the motives were originally measured in individuals by content analysis of Thematic Apperception Test (TAT) responses, the new integrated scoring system, developed by Winter (1983) for scoring motive imagery in any 
kind of verbal material, makes it possible to score presidents at a distance. Thus, both leaders and followers are assessed by means of the same methods and scoring techniques. This makes it possible to describe the characteristics of leaders and situations (or followers) in terms that are both psychologically meaningful and also commensurate with each other. (See Winter, 1973,1983 , for a general description of the psychometric characteristics, including reliability, of the motive measures.)

\section{Method}

\section{Sources of Data}

For each president from Washington through Reagan, the first inaugural address was scored for achievement, affiliation-intimacy, and power motive imagery.' (Presidents Tyler, Fillmore, Andrew Johnson, Arthur, and Ford were never elected and inaugurated in their own right and, therefore, are not included.) Although some speeches had been scored in the past by Donley and Winter (1970) and Winter and Stewart (1977), for the present study all speeches were mixed together and newly scored by two trained and reliable scorers (demonstrated category

Table 1

Motive Imagery Scores of American Presidents' Inaugural Addresses, 1789-1981

\begin{tabular}{|c|c|c|c|c|c|c|c|}
\hline \multirow[b]{3}{*}{ President } & \multirow[b]{3}{*}{ Date } & \multicolumn{6}{|c|}{ Motive scores } \\
\hline & & \multicolumn{3}{|c|}{ Standardized } & \multicolumn{3}{|c|}{ Raw } \\
\hline & & Ach & Aff & Pow & Ach & Aff & Pow \\
\hline Washington, George & 1789 & 39 & 54 & 41 & 3.85 & 3.85 & 4.62 \\
\hline Adams, John & 1797 & 39 & 49 & 42 & 3.89 & 3.03 & 4.76 \\
\hline Jefferson, Thoma & 1801 & 49 & 51 & 51 & 5.65 & 3.30 & 6.59 \\
\hline Madison, James & 1809 & 55 & 51 & 57 & 6.84 & 3.42 & 7.69 \\
\hline Monroe, James & 1817 & 57 & 46 & 51 & 7.22 & 2.41 & 6.62 \\
\hline Adams, John Quincy & 1825 & 48 & 51 & 37 & 5.43 & 3.40 & 3.74 \\
\hline Jackson, Andrew & 1829 & 43 & 47 & 45 & 4.48 & 2.69 & 5.38 \\
\hline Van Buren, Martin & 1837 & 42 & 48 & 40 & 4.38 & 2.83 & 4.38 \\
\hline Harrison, William Henry & 1841 & 32 & 41 & 40 & 2.56 & 1.52 & 4.31 \\
\hline Polk, James & 1845 & 33 & 41 & 50 & 2.65 & 1.43 & 6.32 \\
\hline Taylor, Zachary & 1849 & 53 & 53 & 41 & 6.39 & 3.65 & 4.56 \\
\hline Pierce, Franklin & 1853 & 49 & 44 & 50 & 5.72 & 2.11 & 6.33 \\
\hline Buc & 1857 & 46 & 47 & 42 & 5.05 & 2.53 & 4.69 \\
\hline & 1861 & 36 & 45 & 53 & 3.34 & 2.23 & 6.97 \\
\hline Gra & 1869 & 56 & 47 & 36 & 7.02 & 2.63 & 3.51 \\
\hline Rutherford & 1877 & 51 & 48 & 48 & 6.07 & 2.83 & 6.07 \\
\hline Garfield, James & 1881 & 46 & 35 & 49 & 5.09 & 0.34 & 6.10 \\
\hline Cleveland, Grover & 1885 & 53 & 46 & 63 & 6.52 & 2.37 & 8.89 \\
\hline , Benjamin & 1889 & 37 & 45 & 45 & 3.49 & 2.18 & 5.45 \\
\hline$y$, William & 1897 & 47 & 41 & 46 & 5.30 & 1.51 & 5.55 \\
\hline eft Thedre & 1905 & 62 & 38 & 38 & 8.14 & 1.02 & 4.07 \\
\hline Howard & 1909 & 44 & 38 & 58 & 4.79 & 0.92 & 7.93 \\
\hline Wil & 1913 & 66 & 49 & 53 & 8.83 & 2.94 & 7.06 \\
\hline g, Warren & 1921 & 48 & 57 & 42 & 5.41 & 4.51 & 4.81 \\
\hline Coolidge, Calvin & 1925 & 44 & 46 & 45 & 4.69 & 2.47 & 5.43 \\
\hline Hoover, Herbert & 1929 & 68 & 45 & 48 & 9.18 & 2.16 & 50 \\
\hline Roosevelt, Franklin & 1933 & 53 & 44 & 61 & 6.37 & 2.12 & 8.50 \\
\hline Truman, Harry & 1949 & 56 & 65 & 78 & 6.91 & 5.99 & 11.98 \\
\hline Eisenhower, Dwight & 1953 & 43 & 57 & 49 & 4.50 & 4.50 & 6.14 \\
\hline Kennedy, John & 1961 & 50 & 85 & 77 & 5.90 & 9.59 & 11.81 \\
\hline Johnson, Lyndon & 1965 & 55 & 59 & 49 & 6.77 & 4.74 & 6.09 \\
\hline Nixon, Richard & 1969 & 66 & 76 & 53 & 8.94 & 8.00 & 7.06 \\
\hline & 1977 & 75 & 59 & 59 & 10.60 & 4.89 & 8.16 \\
\hline Reagan, Ronald & 1981 & 60 & 51 & 63 & 7.78 & 3.28 & 9.01 \\
\hline
\end{tabular}

Note. Ach $=$ achievement. Aff $=$ affiliation. Pow $=$ power. agreement with expert scoring over .85 ), who discussed and resolved any disagreements that had occurred. Raw scores were expressed in terms of images per 1,000 words and then standardized with an overall mean of 50 and a standard deviation of 10 for each motive. Motive imagery scores for each president, in standardized and raw form, are presented in Table 1.

Motive scores for American society were adapted from the work of McClelland (1975, chapter 9), who collected three kinds of standard cultural documents dating from each decade from the 1790s through the 1960s: popular novels, children's readers, and hymns. A few details of McClelland's procedure should be mentioned at this point. For each kind of document in each decade, selected pages (readers) or 10-line page segments (novels and hymns) were scored for achievement, affiliation, and power motive imagery. The results were expressed in terms of proportion of pages (or 10-line segments) scored for a particular motive. These scores were then standardized across all decades, separately for each motive. Separate scores from each type of document were then averaged (see McClelland, 1975, pp. 330-332, 403-410, for further methodological information). For the present study, these average decade scores were then restandardized, also with an overall mean of 50 and a standard deviation of 10 for each motive. Thus the motive levels of the presidents and of American society at the time of each president's election are measured in comparable ways and expressed in comparable terms.

\section{Definitions of Variables}

Several characteristics that are important to leader appeal and leader performance in the theories of Freud and Weber, such as energy, impact, prestige, and even narcissism, are closely related to the known action characteristics of the power motive. For example. power-motivated people tend to be energetic, in terms of both self-report and physiological arousal, especially in power-related situations (Steele, 1977). They seek impact on others and are concerned about prestige, while maintaining their own autonomy and self-direction (Winter, 1973; Winter \& Stewart, 1978). Their own estimates of their influence, as well as their responses to ingratiation by subordinates, suggest a considerable narcissism (Fodor \& Farrow, 1979). Thus power motivation is a leader characteristic of great interest in its own right. Some recent studies of organizations further suggest that the combination of high-power motivation and low affiliation-intimacy motivation--the so-called leadership motive pattern-predicts successful leadership among managers and high morale among followers (McClelland, 1975, chapter 8; McClelland \& Boyatzis, 1982; McClelland \& Burnham, 1976). In the present case, this motive combination was defined as the difference be-

\footnotetext{
' When formal prepared speeches are scored, it is natural to ask whether the results reflect the motives of the president or those of the speech writers. There are, however, several reasons for believing that this is not an important problem. First, any good speech writer knows how to produce words and images that feel appropriate and comfortable to the presidential client. Second, before a speech as important as the first inaugural address, presidents spend a good deal of time reviewing and changing the text, paying special attention to the kinds of images that are coded in the motive-scoring systems. For example, the various drafts of President Kennedy's inaugural address show insertions and deletions of scorable imagery, in Kennedy's own handwriting. Many speeches in the Eisenhower Library archives show the same. Thus, although the words may have originated from many sources, in the end an inaugural address probably says almost exactly what the president wants it to say. The final justification of these scores, of course, is their validity in terms of predicting presidential actions and outcomes, as shown in this article and in other studies using the scores.
} 
tween standard-scored power motive imagery and standard-scored affiliation-intimacy imagery. ${ }^{2}$

How can Barber's cyclical theory be operationalized with the motive measures? Barber's three issues seem closely related to the three motives: Conflict suggests power, conciliation suggests affiliation, and (more loosely) conscience may involve achievement. A variable reflecting the cycle-appropriate motive was therefore defined as follows: the power motive score for presidents chosen in the conflict elections $(1912,1924$, $1948,1960)$; the affiliation-intimacy score for presidents taking office in conciliation years $(1908,1920,1932,1968)$; and the achievement score for the winners of conscience elections $(1904,1928,1952,1964$, 1976).

To determine the extent of congruence between a president and American society at the time of his election, the absolute values of the discrepancies between presidential score and society score for each motive were summed to yield a total discrepancy score. With sign reversed, this was used as a measure of president-society motive congruence.

Dependent variables reflecting presidential appeal and presidential performance were taken from several sources. Presidential appeal was measured by the percentage of popular votes received in their first election to the presidency and by the margin of votes over the second-place candidate. (These two measures intercorrelated +.71 , but diverged in years such as $1860,1912,1968$, and 1980 when there were three or more major candidates.) The four cases where the winning candidate was a former vice president who had taken office on the death of the president (Theodore Roosevelt, Coolidge, Truman, and Lyndon Johnson) were eliminated because these men had not initially gained the presidency in their own right. They had no real first election and first inaugural address to study and score. One other measure of presidential appeal, this time involving not only initial popular appeal but also popular reaction to all 4 years of an administration, is whether the president was reelected. Two separate measures were used to measure reelection; one considered each president as a single case (including the four vice presidents mentioned earlier), and the other treated each attempted reelection as a separate case. Obviously those presidents who died during their first term were not included here.

Next, the total national percentage of votes for the House of Representatives candidates of the president's party was taken as a measure of the appeal of the president's party as distinguished from the appeal of the president as a person. (Alternatively, this is a measure of the coattails effect.) Data for these election variables were taken from the Historical Statistics of the United States (Bureau of the Census, 1984).

Generating popular appeal is one kind of political skill, but working successfully with Congress is also important. Although it is difficult to give each president an overall score on his relations with Congress, there are some objective measures that might reflect that relationship, including the number of rejections of court and cabinet appointments (taken from Kane, 1956) and the percentage of vetoes overridden (taken from U.S. Senate Library, 1976). A final aspect of a president's political skill involves his party's election success at the midterm elections 2 years after the inauguration. Normally, the president's party loses seats. In the House of Representatives, the percentage of seats lost varied inversely with the percentage size of the initial majority $(r=-.29$ for 24 midterm elections; percentages rather than raw changes in seats were necessary because of the changing size of the U.S. House of Representatives over time). When the effects of this negative correlation were removed by subtracting the expected loss from the actual loss, the result was an adjusted measure of the performance of the president's party.

Of the many things that can happen in a presidential administration, war and peace are surely among the two most important. In the present study, war entry was defined in terms of the list developed by Richardson (1960), with his definitions used for the years before 1820 and after 1945. (Because of the difficulty of demarcating separate wars and the uncertainty of casualty figures, all Indian conflicts are excluded. Thus in the present context, war really means interstate war.) Not every crisis necessarily results in war, however. Small (1980), for example, listed 19 crises that could easily have escalated into war but that were in fact settled peacefully. Some examples include the dispute with England about violations of American neutrality (1791), the Oregon boundary dispute (1845), the Panay incident (1937), and the Cuban Missile Crisis (1962). These are labeled war avoidance in the present study. Another aspect of peacemaking involves the limitation of arms. Starting with the first arms limitation conference at The Hague during McKinley's administration, historical sources were used to identify presidents who concluded treaties with at least one other major power for the limitation or banning of one or more specific weapons systems.

What is presidential greatness? Perhaps it is impossible to define. First, we can never know all the facts about a president's actions and what independent effects these actions had on historical outcomes. Even with these facts, moreover, any ratings of greatness will mostly reflect the values attached by the rater to these outcomes. For example, raters who value military greatness will tend to rate highly presidents who involved the United States in victorious wars. Second, presidential greatness probably has many separate (and uncorrelated) components. How can these be weighed and synthesized into a single rating?

One approach to measuring presidential greatness is to rely on the judgments of scholars of American history. Although their judgments are undoubtedly affected by their values, historians are presumably in possession of more facts than are most people and are in a better position to make objective evaluations and comparative ratings. Over the past 35 years, historians have often been polled on presidential greatness. In one of the most extensive polls, Maranell (1970) asked 571 historians of the United States to rate the presidents on several dimensions, including general prestige, strength of action, presidential activeness, and accomplishments of the administration. Because these four dimensions were highly intercorrelated, they were standardized and summed to produce a consensus on the relative greatness of the presidents from Washington to Lyndon Johnson. Washington and Lincoln, for example, were the highest rated presidents, whereas Grant and Harding were at the bottom. In a sense, these ratings are only another aspect of presidential appeal, to historians rather than to voters. In fact, though, the correlations between the summed Maranell study ratings and the percentage of vote and margin of victory measures were essentially zero. At the very least, then, rated greatness is different from voter appeal. Another facet of presidential greatness involves making decisions that have historic impact on the country and world, as compiled and judged by Morris (1967). Some examples of "great" presidential decisions include the purchase of Louisiana (by Jefferson), the abolition of central banking (by Jackson), and the attack on business trusts (by Theodore Roosevelt).

\section{Results}

Table 2 presents the relations between each of the four major variables assessing presidential motives or president-situation motive match and the dependent variables reflecting presidential appeal, political skill, and presidential performance. Presidential appeal, as measured by success at both election and reelection, is a straightforward function of how congruent the president's motive levels were with those of the American society of the time. The much lower correlation with the total per-

\footnotetext{
${ }^{2}$ Subtracting standardized affiliation-intimacy from standardized power motivation follows the practice of these researchers and also yields a single variable combining the two motives that can be simply represented and used in correlations, as in Table 2. It would also be possible to combine the two motive scores by means of multiple regression (in which case an interaction term could also be used). Although such a procedure might be more powerful statistically, it is also more complex and is not the same combination measure used by McClelland and others.
} 
Table 2

Correlations of Variables Assessing Aspects of Presidential Appeal and Performance

With Presidential Characteristics and President-Situation Match

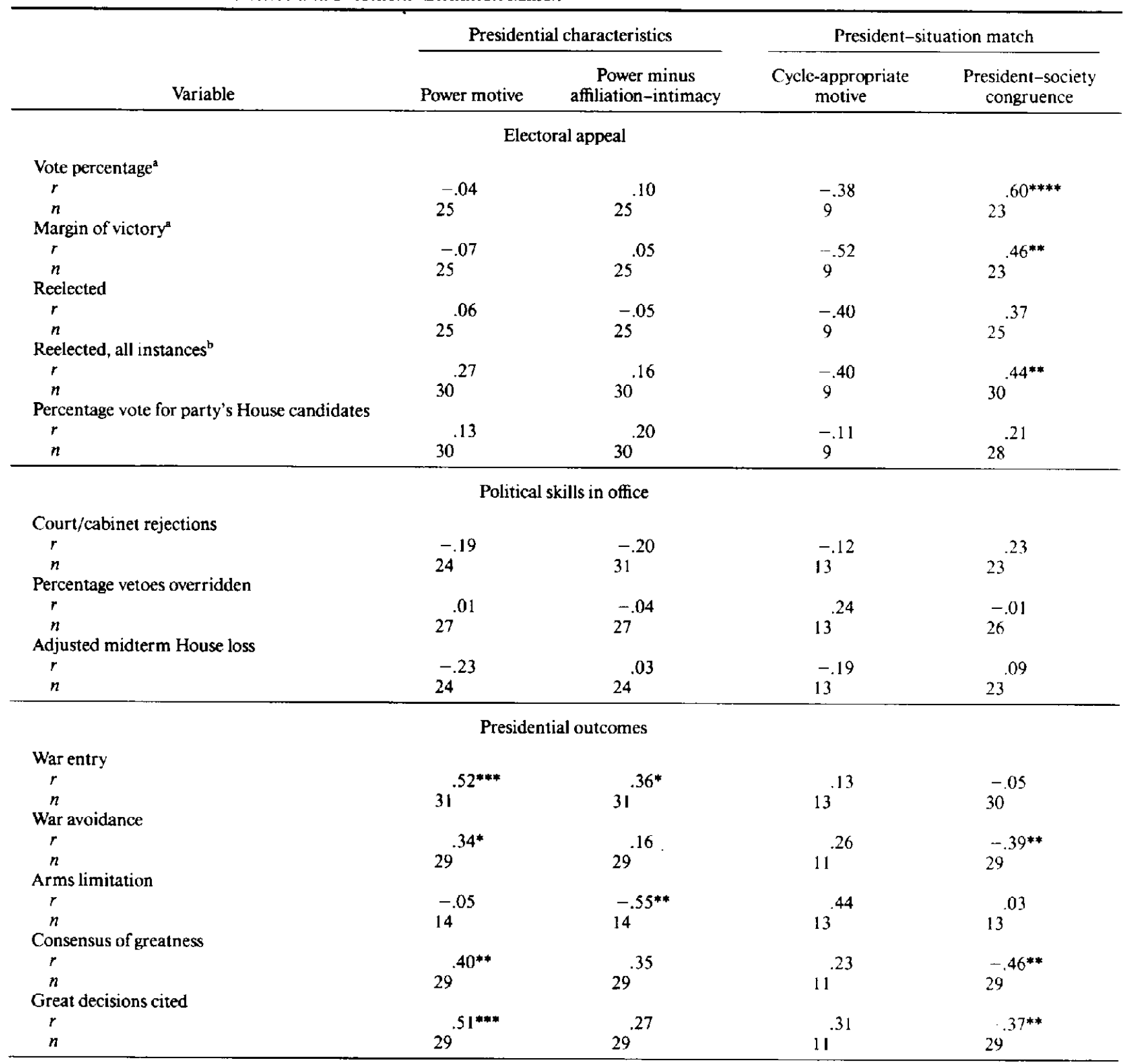

- Excluding all vice presidents who assumed office on the death of the president.

b Including all attempts at reelection.

${ }^{*} p<.10$, two-tailed. ${ }^{* *} p<.05$, two-tailed. ${ }^{* * *} p<.01$, two-tailed. ${ }^{* * * *} p<.001$, two-tailed.

centage of House of Representatives vote for candidates of the president's party suggests that this motive congruence predicts the specific personal appeal of the president (percentage of votes cast, margin, reelection), rather than the national support for the president's party (or the coattails effect). In general, the summed discrepancy/congruence score gave results more significant than those for the discrepancy scores on any individual motive, suggesting that discrepancies on each motive contributed to most overall effects. Algebraically signed discrepancy scores gave no significant results. This suggests that what is important is the discrepancy between president and society, rather than whether the president or the society is higher on any particular motive.

Neither presidential power motivation nor power minus affiliation-intimacy, by itself, was related to any aspect of political appeal. The cyclically appropriate motive measure, drawn from Barber's theory, actually reversed and was negatively correlated with most of the appeal measures. For political appeal, 
as reflected in the size of the personal electoral mandate, then, Erikson's theory of leader-follower personality congruence was the theory most strongly supported by the results.

None of the measures of political skill in office was significantly associated with any of the presidential or congruence motive measures. Probably veto overrides and appointment rejections are fragmentary measures that do not adequately reflect presidential political skill and are much affected by particular historical circumstances.

Presidential outcomes showed a very different pattern. Power motivation was strongly related to war entry, as expected on the basis of numerous other findings (e.g., Winter, 1980). It was also related, almost at a significant level, to avoiding war in a crisis situation. This suggests that the power motive is a leader characteristic associated with dramatic, crisis-oriented, perhaps confrontational foreign policy, which may end peacefully but which can easily end in war (see Hermann, 1980). Power motivation by itself was also associated with both measures of greatness, more strongly so than power minus affiliation-intimacy or the leadership motive pattern. This latter variable was negatively associated with arms reduction, largely because of the strong positive relation between affiliation-intimacy imagery and arms limitation agreements $(r=.43)$. The cycle-appropriate motive measure also showed low, nonsignificant correlations in the same direction as those for the power motive. Congruence between president and society, in contrast, was significantly negatively associated with both measures of greatness as well as war avoidance. It seems those presidents who matched the country's motives at the time were in the end among the least great of the presidents, at least in the judgment of historians.

\section{Discussion}

These results suggest two conclusions. First, among American presidents at least, leader appeal is a function of how well the leader's own motives fit the motive imagery profile of the times. Presidential leadership performance, however, is a very different matter. Both rated performance and several of the most significant outcomes were functions more of leader attributes (especially power motivation) than of leader-situation match. Indeed, among American presidents it appears that the greatest presidents were those who were least congruent with the followers of their society.

Some examples will illustrate these two conclusions. Abraham Lincoln is generally considered to be one of the two greatest American presidents. Yet he was one of four major candidates in 1860 , elected with only a minority of the total popular vote. His motive profile was highly discrepant with that of American society in the $1860 \mathrm{~s}$; in fact, he is among the half dozen most discrepant presidents. Some others with motive profiles highly discrepant from their times include: Washington, Theodore Roosevelt, Truman, and Kennedy-all highly rated by historians. And some congruent presidents include Buchanan, Grant, Harding, and Coolidge-three of whom are considered to be failures if not outright disasters. (To be fair, it must also be noted that Franklin Roosevelt was highly congruent and Nixon highly discrepant.)

These results diverge somewhat from those obtained by $\mathrm{Si}-$ monton (1981) in his study of presidential greatness (summed ratings along five dimensions, from Maranell) and presidential performance (duration of administration, war years, assassination attempt, and scandal). Simonton found that personality traits, including specifically achievement and power motivation scores, made little predictive contribution to presidential greatness or performance. How can this conclusion be reconciled with the results of the present study? First, there are differences in the motive scores used. Simonton used scores originally reported by Donley and Winter (1970), based on an informal adaptation of the original scoring systems, for the 12 presidents from 1905 to 1969 . When the final codified version of the integrated scoring system was developed (Winter, 1983), the first inaugurals of all presidents were mixed together and scored. This resulted in some changed scores for speeches scored earlier, most notably for Theodore Roosevelt and William Howard Taft. The later scorings, shown in Table 1, should be taken as definitive. Thus the present study involved slightly different motive data and used a much larger group of presidents. Second, Simonton used some presidential performance variables that were different from those of the present study and others that were defined differently. For example, Simonton did not measure war avoidance, arms limitation, or great decisions; and the definitions of one overlapping variable-war-seem to be different in the two studies. Finally, Simonton analyzed the effect of motives "within a multivariate framework" (1981, p. 321), which seems to mean hierarchical regression (cf. p. 314), although this is not clear. No doubt different researchers would make different judgments about whether, in predicting performance and greatness, personality variables should be entered before or after variables reflecting other biographical information or administration events. Simonton did not investigate the relation between presidential and societal motives. Overall, then, the differences in the results of these two studies suggest the need for careful definition of variables and explicit theory about the relation of leader motivation to other kinds of variables.

Although the present results are based on a small population of leaders and measures that involve several assumptions, they do suggest some interesting hypotheses about leadership in the real world of politics: (a) Leader appeal seems to involve a person-situation (or leader-follower) match on psychological characteristics. (b) Leader performance (historically rated greatness and some major outcomes), when it is more than a function of circumstances, may involve more enduring and less situationally defined psychological characteristics of the leader.

Why do these conclusions diverge from much of the experimental social psychological research on leadership? The timebound constraints of the laboratory often lead researchers to rely on group member sociometric ratings of leadership; that is, leader appeal. Not surprisingly, the results often involve some kind of complex leader-situation interaction. But factors that predict leadership that is sociometrically defined in this way may not necessarily predict long-term effective leader performance and evaluation, which of course is hard to study in the time-foreshortened laboratory microcosm. This divergence of leader appeal and leader performance should underline the importance of studying leadership in the real world, using archival, at-a-distance measures.

The conclusions of the present study are also relevant to the basic philosophical assumptions of democratic political theory. We may vote for the candidate who feels most "comfortable" 
or congruent to us, who fits our dimly perceived hierarchies of motives and goals. At best, though, such leader appeal has little to do with leader effectiveness. And often enough the "uncomfortable" leader, discrepant in motive from the larger society of the times, turns out to be regarded as the great leader.

\section{References}

Allport, G. W. (1937). Personality: A psychological interpretation. New York: Holt.

Bales, R. F. (1970). Personality and interpersonal behavior. New York: Holt, Rinehart \& Winston.

Barber, J. D. (1980). The pulse of politics: Electing presidents in the media age. New York: Norton.

Bass, B. M. (1981). Stogdill's handbook of leadership (rev. ed.). New York: Free Press.

Bem, D. J., \& Funder, D. C. (1978). Predicting more of the people more of the time: Assessing the personality of situations. Psychological Review, 85, 485-501.

Bem, D. J., \& Lord, C. G. (1979). Template-matching: A proposal for probing the ecological validity of experimental settings in social psychology. Journal of Personality and Social Psychology, 37, 833-846.

Brown, R. W. (1965). Social psychology. New York: Free Press.

Bureau of the Census. (1984). Historical statistics of the United States. Washington, DC: U.S. Government Printing Office.

Bums, J. M. (1956). Roosevelt: The lion and the fox. New York: Harcourt, Brace.

Conte, H. R., \& Plutchik, R. (1981). A circumplex model for interpersonal personality traits. Journal of Personality and Social Psychology. 40,701-711.

Donley, R. E., \& Winter, D. G. (1970). Measuring the motives of public officials at a distance: An exploratory study of American presidents. Behavioral Science, 15, 227-236.

Erikson, E. H. (1950). Childhood and society. New York: Norton.

Erikson, E. H. (1958). Young man Luther. New York: Norton.

Erikson, E. H. (1964). Insight and responsibility: New York: Norton.

Erikson, E. H. (1969). Gandhi's truth. New York: Norton.

Fodor, E. M., \& Farrow, D. L. (1979). The power motive as an influence on use of power. Journal of Personality and Social Psychology, 37 , 2091-2097.

Freud, S. (1955). Group psychology and the analysis of the ego. In J. Strachey (Ed.), Standard edition of the complete psychological works of Sigmund Freud (Vol. 18, pp. 67-143) London: Hogarth. (Original work published 1921)

Gibb, C. A. (1969). Leadership. In G. Lindzey \& E. Aronson (Eds.), Handbook of social psychology (rev. ed.). Reading, MA: AddisonWesley.

Haley, J. (1969). The power tactics of Jesus Christ and other essays. New York: Grossman.

Hermann, M. G. (Ed.). (1977). A psychological examination of political leaders. New York: Free Press.

Hermann, M. G. (1980). Explaining foreign policy using personal characteristics of political leaders. International Studies Quarterly, 24, 746.

Hollander, E. P. (1964). Leaders, groups and influence. New York: Oxford University Press.

Kane, J. N. (1956). Facts about the presidents (3rd ed.). New York: H. W. Wilson.

Magnusson, D., \& Endler, N. S. (Eds.). (1977). Personality at the cross- roads: Current issues in interactional psychology. Hillsdale, NJ: Erlbaum.

Maranell, G. (1970). The evaluation of presidents: An extension of the Schlesinger poll. Journal of American History, 57, 104-113.

McAdams, D. P. (1982). Intimacy motivation. In A. J. Stewart (Ed.), Motivation and society. San Francisco: Jossey-Bass.

McClelland, D. C. (1961). The achieving society. Princeton. NJ: Van Nostrand.

McClelland, D. C. (1975). Power: The inner experience. New York: Irvington.

McClelland, D. C., \& Boyatzis, R. E. (1982). Leadership motive pattern and long-term success in management. Journal of Applied Psychology, 67, 737-743.

McClelland, D. C., \& Burnham, D. (1976). Power is the great motivator. Harvard Business Review, 54, 100-111.

Mischel, W. (1968). Personality and assessment. New York: Wiley.

Morris, R. B. (1967). Great presidential decisions: State papers that changed the course of history (rev. ed.). Philadelphia: Lippincott.

Murray, R. K., \& Blessing, T. H. (1983). The presidential performance study: A progress report. Journal of American History. 70, 535-555.

Nie, N. H., Verba, S., \& Petrocik, J. R. (1979). The changing American voter (enlarged ed.). Cambridge, MA: Harvard University Press.

Richardson, L. (1960). Statistics of deadly quarrels. Pittsburgh, PA: Boxwood Press.

Sears, D. O. (1969). Political behavior. In G. Lindzey \& E. Aronson (Eds.), Handbook of social psychology (Rev. ed., Vol. 5, pp. 315-458). Reading, MA: Addison-Wesley.

Simonton, D. (1981). Presidential greatness and performance: Can we predict leadership in the White House? Journal of Personality: 49. 306-323.

Small, M. (1980). Was war necessary? National security and United States entry into war. Beverly Hills, CA: Sage.

Snider, J. G., \& Osgood, C. E. (Eds.). (1969). Semantic differential technique: A sourcebook. Chicago: Aldine.

Steele, R. S. (1977). Power motivation, activation, and inspirational speeches. Journal of Personality; 45, 53-64.

U.S. Senate Libary. (1976). Presidential vetoes, 1789-1976. Washington, DC: U.S. Government Printing Office.

Vidal, G. (1984). Lincoln. New York: Random House.

Weber, M. (1947). The theory of social and economic organization. New York: Free Press.

Wiggins, J. S. (1980). Circumplex models of interpersonal behavior. In L. Wheeler (Ed.), Review of personality and social psychology (Vol. 1, pp. 265-294). Beverly Hills, CA: Sage.

Winter, D. G. (1973). The power motive. New York: Free Press.

Winter, D. G. (1980). Measuring the motives of southern Africa political leaders at a distance. Political Psychology, 2(2), 75-85.

Winter, D. G. (1983). Development of an integrated system for scoring motives in verbal running text. Unpublished manuscript, Wesleyan University, Middletown, CT.

Winter, D. G., \& Stewart, A. J. (1977). Content analysis as a method of studying political leaders. In M. G. Hermann (Ed.), A psychological examination of political leaders (pp. 27-61). New York: Free Press.

Winter, D. G., \& Stewart, A. J. (1978). Power motivation. In H. London \& J. Exner (Eds.), Dimensions of personality (pp. 391-447). New York: Wiley.

Received September 28, 1984

Revision received March 4, 1985 